\title{
Effects of type of carbohydrate during proliferation and rooting of microcuttings of Malus Jork 9
}

\author{
C Moncousin, M Ribaux, J O'Rourke, S Gavillet \\ Centre horticole de Lullier, Ecole d'ingénieurs, $\mathrm{CH}, 1254$ Jussy, Geneva, Switzerland
}

(COST Meeting, 21-23 May 1992, Dijon, France)

\begin{abstract}
Summary - The type of carbohydrate used in the medium influenced the proliferation of Malus Jork 9. The microcuttings obtained showed marked differences in rooting ability. During proliferation, sorbitol $(0.176 \mathrm{M})$ gave the best results. The plants grown on fructose (either directly added or resulting from the hydrolysis of sucrose) showed a definite tendency to become an unorganised structure. This abnormal growth showed similarities with the "cancerisation" of microcuttings in the presence of very high cytokinin levels! This BAP toxicity could be caused by a higher contact surface due to softer gel, this in turn being caused by lowering of $\mathrm{pH}$ after autoclaving. During rooting, it seems that both the sugar used during proliferation and that present in the rooting medium influenced the criteria chosen. The best results were obtained with sucrose $(0.088 \mathrm{M})$ during proliferation and glucose $(0.088 \mathrm{M})$ during rooting. Statistically, however, they did not differ from sorbitol $(0.176 \mathrm{M})$ used during both phases of culture.
\end{abstract}

Malus domestica Borkh Jork 9 / carbohydrate / proliferation / rooting / cancer

Résumé - Effet du type de glucide utilisé durant la prolifération et l'enracinement de microboutures de Malus Jork 9. Le type de glucide utilisé dans les milieux de culture in vitro influence la capacité de prolifération intensive de Malus Jork 9. Les microboutures obtenues montrent de nettes différences dans leur capacité rhizogène exprimée par le pourcentage d'enracinement et par le nombre de racines formées par bouture. En phase de prolifération, le sorbitol $\left(0,176 \mathrm{~mol}^{\left.-1^{1}\right)}\right.$ donne des résultats statistiquement supérieurs à tout autre traitement. Les plantes se développant sur un milieu de culture contenant du fructose (apporté directement ou résultant de l'hydrolyse du saccharose) montrent une tendance marquée de passage de l'état "touffes" à celui de structure inorganisée. La capacité de récupération d'une croissance normale est inversement proportionnelle au nombre de subcultures et à la quantité de fructose présente dans le milieu. Les perturbations de croissance en présence de fructose montrent des analogies avec la "cancérisation" des microplants rencontrée lors d'apports excessifs de cytokinine ! Cette intoxication par la $B A P$ pourrait trouver son origine dans une augmentation des surfaces de contact à la suite d'une dureté du gel plus faible consécutive à un abaissement accru du pH au cours de l'autoclavage. En phase d'enracinement, il apparaît que le sucre utilisé durant la prolifération comme dans le milieu de rhizogenèse influence les 2 critères susmentionnés. Les meilleurs résultats obtenus en utilisant le saccharose $\left(0,088\right.$ mol..$\left.^{-1}\right)$ en phase de prolifération et le glucose $\left(0,088\right.$ mol. $\left.^{-1}\right)$ en phase d'enracinement ne diffèrent pas statistiquement de ceux obtenus avec l'emploi du sorbitol $\left(0,176\right.$ mol..$\left.^{-1}\right)$ pendant les 2 phases de culture.

Malus domestica Borkh Jork 9 / glucide / prolifération / enracinement / cancer 


\section{INTRODUCTION}

The carbohydrate composition of the medium is a key factor in micropropagation, since the formation of organs requires high energetic levels and the cultures are usually heterotrophic (Thorpe, 1980; Kozai, 1991). In Rosaceae callus, sucrose, fructose, glucose and sorbitol can be used with success, but there is a nutritional preference depending on the genotype used (Chong and Taper, 1974; Cofin et al, 1976). In culture media used for intensive proliferation of Malus, sucrose is the most frequently utilized carbon source. Its concentration varies between 2-3\% (James et al, 1979; Snir and Erez, 1980; James and Thurbon, 1981). Whereas fructose and glucose have been tested in micropropagation with mitigated results, the use of sorbitol is more recent. Chong and Taper (1974) have shown that this carbohydrate is a key element in the carbon metabolism of the Rosaceae family and is both a respiration substrate and a form of potential storage. The use of sorbitol in in vitro cultures only really started with the studies of Eng-Chong (1983). He observed that in the micropropagation of Malus the proliferation rate and length of shoots were directly related to the type of carbohydrate and its concentration. The ability to utilise and store sucrose and sorbitol is not only a genotypic consequence, but also dependent on the ontogenetic state of the tissues. Identical amounts of sorbitol and sucrose were found in apple callus initiated from young seedlings, whereas in callus initiated from old tissues, sucrose was the main accumulated form of sugar (Grant and Rees, 1981). The capacity to convert fructose, glucose and sucrose into sorbitol (and vice versa) by non-photosynthetic apple tissues has been proven (Eng-Chong, 1983). The use of sucrose in the medium is problematical. It is usually considered that after autoclaving, sucrose undergoes an uncertain percentage of hydrolysis depending on sterilisation conditions (George and Sherington, 1984). In our conditions, $\approx 6 \%$ of the sucrose is hydrolysed, even though hydrolysis continues during almost the entire subculture of Malus (unpublished results). The comparison of the influences of sucrose and hydrolysed sucrose respectively according to the method of Druart and De Wulf (1990) has shown with Malus EM IX that the immediate availability of fructose and glucose has a favourable influence on proliferation rate (Seingre et al, 1991).

In rhizogenesis, high concentrations of sucrose have negative effects. This can be ex- plained by the accumulation of rooting inhibitors, the reduction of promotors (Eliasson and Brunes, 1980), and the transformation of added sugars into soluble and storage form (Haissig, 1984), but also by the fact that the nitrogen-sucrose (Hyndman et al, 1982; Driver and Suttle, 1987) and auxin-sucrose ratios (Welander, 1976) influence the rooting process. This is why the majority of rooting media contain little sucrose; in the literature we find media with $5 \mathrm{~g} / \mathrm{l}$ of sucrose (Chalupa, 1977; Cheng and Voqui, 1977; Boulay, 1979; Timmis and Ritchie, 1984), but in $70 \%$ of the cases doses of 10-20 g/l have been mentioned for both herbaceous and woody plants.

We have tested the effect of sucrose concentration on rooting in various plants such as globe artichokes, vines, fuchsias, platycerium, or apple trees. For Malus EMLA 9, the best results are obtained with 20 or $30 \mathrm{~g} / \mathrm{l}$ sucrose but for most of the tested plants the best concentration is $20 \mathrm{~g} / \mathrm{l}$ (Moncousin, 1992). Preliminary experiments (Seingre et al, 1991) have shown a definite influence of the carbon source and its concentration on the in vitro proliferation and adventitious rooting. Here we report on the behaviour of microcuttings derived from 12 different media ( 6 different carbon sources at 2 concentrations) and rooted on 3 different media which also differ in their sugar content.

\section{MATERIALS AND METHODS}

\section{Plant material}

The plant material used is an apple rootstock Jork 9, obtained directly from B Kunneman (COWT, Lisse, The Netherlands) within the EEC Cost 87 action. The plants were already established in vitro and were cultured on the various sugars for 3 subcultures before the experiments started.

\section{Proliferation phase}

The plants were formed in shoot tufts varying between $1-3 \mathrm{~cm}$ in length. To multiply the plants, an apex of $0.5 \mathrm{~cm}$ was excised and transferred to fresh medium. This phase took place in glass jars containing $100 \mathrm{ml}$ medium which, once closed, were covered with Saran film (PVDC Dow Chemical).

The multiplication medium, preparation of the hydrolysed sucrose and culture room conditions have been described by Seingre et al (1991). 
During the proliferation experiments, the multiplication medium remained unchanged except for the carbon source (see table I for various conditions). The length of subculture was $6 \mathrm{wk}$ independent of the carbohydrate used.

\section{Rooting phase}

Shoots $2 \mathrm{~cm}$ in length were harvested at the end of the multiplication stage and received a short treatment with auxin before transfer to basal medium (medium identical to the multiplication medium but hormone-free).

The short treatment with auxin consisted of 2-h soaking of the microcutting base $(2-3 \mathrm{~mm})$ in a $2 \mathrm{mM}$ IAA agarised solution. After transfer, the plants were kept in darkness at $26{ }^{\circ} \mathrm{C}$ for $6 \mathrm{~d}$ and then placed in the culture chamber. The auxin treatment took place in plastic jars and rooting was performed in tubes closed with Magenta caps. The plants used for rooting were harvested from the 12 different carbon sources used during proliferation. After the auxin treatment they were rooted on 3 different sugars: a) the same sugar at the same molarity as during multiplication; b) sucrose at $0.088 \mathrm{M}$; c) glucose at $0.176 \mathrm{M}$.

\section{Criteria and statistical methods}

The multiplication rate expressed is the No of usable shoots per tuft. Twenty-two individuals were used per treatment, and 3 repetitions were performed.

In the rooting experiments the rooting response was measured as the ratio of the number of roots produced/total No of shoots, and as rooting $\%$ after 3 wk. Three repetitions were carried out and 22 individuals recorded per treatment.

Results were compared: a) for the same sugar at various molarities; b) at the same molarity for the various sugars. We considered that hydrolysis was not significant for sucrose but that it was complete for hydrolysed sucrose! The results were analysed using statistical software (GB-STAT, Dynamic Microsystems Inc).

\section{RESULTS AND DISCUSSION}

\section{Proliferation}

A global comparison (using all the sugars at the various molarities) showed that Sor30 was statistically superior to standard (Suc30) used in the present study and only Sor15 was identical to it (Dunnett test, 99\% probability). The carbohydrates had a large effect both on proliferation rates (table II), and on the quality of the plant material. At the high molarity, sorbitol was superior
Table I. Presentation of the symbols used for the experiments at various molarities.

Sugar $\frac{\text { Molarity before autoclaving }}{0.175 \mathrm{M} \quad 0.088 \mathrm{M} \quad 0.044 \mathrm{M}}$

$\begin{array}{llll}\text { Sucrose } & & \text { SUC30 } & \text { SUC15 } \\ \text { Sorbitol } & \text { SOR30 } & \text { SOR15 } & \\ \text { Fructose } & \text { FRU30 } & \text { FRU15 } & \\ \text { Glucose } & \text { GLU30 } & \text { GLU15 } & \\ \text { Fructose + glucose } & \text { F+G30 } & \text { F+G15 } & \\ \text { Hydrolysed sucrose } & & \text { SHY30 } & \text { SHY15 }\end{array}$

to all other treatments, but at the lower molarity sucrose and sorbitol did not differ (Gupta test, $99 \%$ probability).

The cultures of Fru30, Fru15, Shy30, Shy15 and $\mathrm{F}+\mathrm{G} 15$ (fig 1) showed a rapid decline in ability to proliferate, and it was not possible to maintain these plants in culture after the 5th subculture. A neoplastic progression towards vitrification was noted; ie from normal organs of plants to unorganised structures (Gaspar et al, 1991) (fig 2). This aspect is directly opposed to the possibility of recuperating the plants by passage on sorbitol or sucrose-containing media. In the first stage of this growth degradation, stems and leaves obtained all showed morphological signs of intense rejuvenation with, however, a reduction in shoot size (the appearance of the shoots alters from tuft to teratoma).

Table II. Results of the proliferation experiment measured in the number of shoots per tuft after 6 wk on the various sugars.

\begin{tabular}{lccc}
\hline & \multicolumn{3}{c}{ Molarity } \\
\cline { 2 - 4 } Sugar & $0.176 \mathrm{M}$ & $0.088 \mathrm{M}$ & $0.044 \mathrm{M}$ \\
& & & \\
\hline & & $4.2 \pm 0.3^{\mathrm{a}}$ & $2.2 \pm 0.2$ \\
Sucrose & $6.0 \pm 0.3^{\mathrm{a}}$ & $3.9 \pm 0.3^{\mathrm{a}}$ & - \\
Sorbitol & $2.8 \pm 0.2$ & $3.1 \pm 0.2$ & - \\
Glucose & $2.7 \pm 0.2$ & $1.6 \pm 0.1$ & - \\
Fructose + glucose & & \\
Hydrolysed sucrose $1.3 \pm 0.2$ & $1.3 \pm 0.1$ & - \\
Fructose & $0.4 \pm 0.1$ & $1.4 \pm 0.2$ & - \\
& & & \\
Statistical analysis & $P<0.0001$ & $P<0.0001$ & \\
\hline
\end{tabular}

a: treatments which are statistically superior to others, using Gupta's test at a $99 \%$ probability level. 


\section{SUGARS}

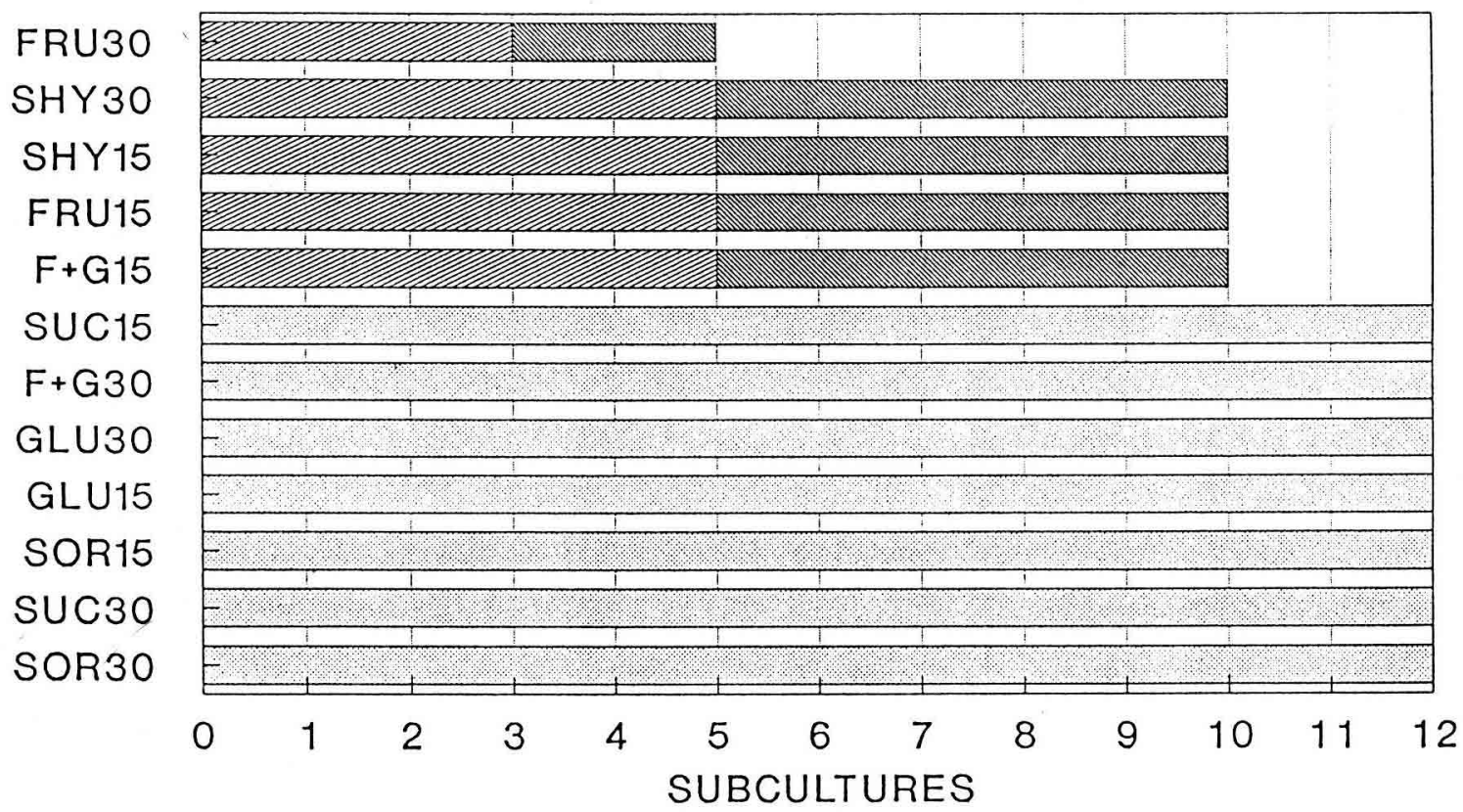

Fig 1. The effect of carbohydrates and their concentration on the ability to maintain a proliferation rate $>2$, between 1 and 2 , or $<1$.

Pair comparison of the proliferation rates showed that molarity did not always have the same effect (table III); doubling the molarity statistically increased propagation for sorbitol, sucrose and fructose + glucose, but had no effect on glucose and hydrolysed sucrose. Contrary to previously obtained results (Seingre et al, 1991), hydrolysed sucrose was always statistically inferior to sucrose. Hydrolysed sucrose and fructose + glucose provided identical results at the lower molarity, but hydrolysed sucrose was inferior at the higher concentration. An assessment of these comparisons showed a negative effect due to the presence of fructose.
Preliminary experiments have shown relations between the molarity of fructose, $\mathrm{pH}$ and gel strength, and we have also noted a direct relation between gel strength and Jork 9 proliferation (quantity and quality levels!).

\section{Rooting}

In general, the rooting \% was statistically less influenced by the various carbohydrates than the number of roots formed per shoot after $21 \mathrm{~d}$.

Comparison of results obtained with plants generated from media with $0.088 \mathrm{M}$ sugar and

Table III. Paired statistical comparisons ( $t$-test) of the proliferation results obtained with the various sugars and their molarities.

\begin{tabular}{|c|c|c|c|c|c|c|c|c|}
\hline SOR30 & SUC30 & GLU30 & SHY30 & $F+G 30$ & FRU30 & SUC30 & SUC15 & $\mathrm{F}+\mathrm{G} 30$ \\
\hline & $>$ & $=$ & $=$ & $>$ & $<$ & $>$ & $>$ & $>$ \\
\hline$\underset{\star \star \star \star}{\text { SOR15 }}$ & $\underset{\star \star \star \star}{\text { SUC15 }}$ & $\begin{array}{c}\text { GLU15 } \\
\text { NS }\end{array}$ & $\begin{array}{c}\text { SHY15 } \\
\text { NS }\end{array}$ & $\underset{\star \star \star \star}{F}+\mathrm{G} 15$ & $\underset{\star \star \star \star \star}{F R U 15}$ & $\underset{\star \star \star \star \star}{\text { SHY30 }}$ & $\underset{* \star}{\text { SHY15 }}$ & $\underset{\star \star \star \star \star}{\text { SHY3O }}$ \\
\hline $\mathrm{F}+\mathrm{G} 15$ & GLU30 & GLU15 & $F+G 15$ & $\mathrm{~F}+\mathrm{G} 30$ & GLU15 & GLU30 & SUC30 & SUC15 \\
\hline$=$ & $>$ & $>$ & $=$ & $>$ & $>$ & $=$ & $>$ & $>$ \\
\hline SHY15 & FRU30 & FRU15 & FRU15 & FRU30 & $F+G 15$ & $\mathrm{~F}+\mathrm{G} 30$ & $F+G 15$ & $\mathrm{~F}+\mathrm{G} 15$ \\
\hline NS & $\star \star \star \star *$ & 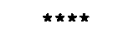 & NS & 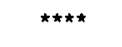 & 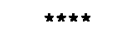 & NS & 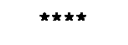 & $\star$ \\
\hline
\end{tabular}


rooted on sucrose at the same molarity showed a significant difference with rooting \%, and a highly significant difference with the number of roots formed per treated shoot (table IV). With the same conditions but when testing rootability of shoots from the higher molarity, statistically the same results were found.

If rooting took place on a medium containing glucose, there was a statistical difference in the number of roots formed whatever the molarity of the sugar in the proliferation medium. When the type of carbohydrate and the molarity were identical during both phases of culture, statistical differences were found: a) in the number of roots, whatever the molarity $(0.088$ or $0.176 \mathrm{M})$; b) in rooting $\%$ whatever the molarity, but not at the same statistical probability.

If we consider the results obtained for each carbohydrate, a favourable effect of sucrose and glucose during rooting was found, but the interesting results obtained with sequence Sor30Sor30 should be noted. We must also underline that whatever the sugar used during rooting and whatever the molarity during proliferation, the best results in both the comparison criteria selected were provided by the media which contained no or practically no fructose.

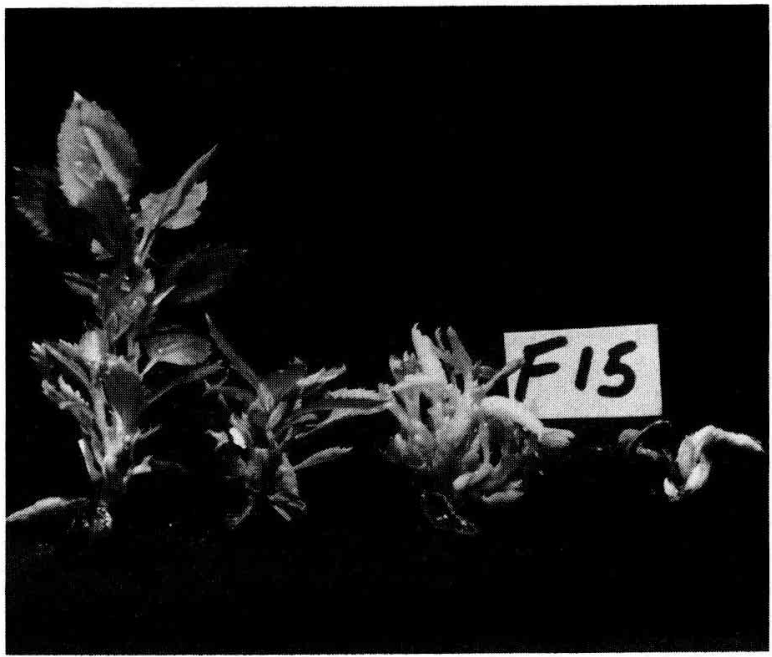

Fig 2. "Cancerisation" states found at the 4th subculture of Malus Jork 9 on fructose at $0.088 \mathrm{M}$ (from left to right : normal plant with poor proliferation, BAP intoxicated plant, BAP vitrified plant and "cancerised" plant).

Table IV. Rooting results, in number of roots and rooting \% (after $21 \mathrm{~d}$ ), according to the various sugar and their molarities.

\begin{tabular}{|c|c|c|c|c|c|c|}
\hline \multirow[b]{3}{*}{ Proliferation sugar } & \multicolumn{6}{|c|}{ Rooting sugar } \\
\hline & \multicolumn{2}{|c|}{ Sucrose 30} & \multicolumn{2}{|c|}{ Glucose 30} & \multicolumn{2}{|c|}{ Same sugar - same molarity } \\
\hline & No roots & $\%$ & No roots & $\%$ & No roots & $\%$ \\
\hline SOR 15 & $3.05^{\mathrm{a}}$ & $63^{a}$ & 2.15 & $70^{\mathrm{a}}$ & 1.36 & $58^{a}$ \\
\hline SUC 30 & $2.78^{a}$ & $59^{a}$ & $4.30^{\mathrm{a}}$ & $\underline{83}$ & $2.78^{a}$ & $59^{a}$ \\
\hline GLU 15 & $2.56^{\mathrm{a}}$ & $56^{a}$ & 2.08 & $58^{a}$ & 1.77 & $58^{a}$ \\
\hline $\mathrm{F}+\mathrm{G} 15$ & 0.70 & 39 & 1.20 & 37 & 0.77 & 37 \\
\hline SHY 15 & 1.71 & 33 & 2.51 & 40 & 0.78 & $42^{a}$ \\
\hline FRU 15 & 0.85 & 33 & 1.20 & 37 & 0.29 & 24 \\
\hline Statistical analysis & $P<0.0001$ & $P<0.095$ & $P<0.0002$ & $P<0.086$ & $P<0.0001$ & $P<0.099$ \\
\hline SOR 30 & $3.59^{\mathrm{a}}$ & $68^{a}$ & $2.64^{a}$ & $72^{\mathrm{a}}$ & $3.86^{a}$ & $79^{a}$ \\
\hline GLU 30 & $3.30^{\mathrm{a}}$ & $60^{\mathrm{a}}$ & $3.30^{a}$ & $69^{a}$ & $3.30^{\mathrm{a}}$ & $69^{a}$ \\
\hline $\mathrm{F}+\mathrm{G} 30$ & $3.69^{\mathrm{a}}$ & $75^{a}$ & $3.36^{a}$ & $72^{\mathrm{a}}$ & 1.50 & $39^{a}$ \\
\hline SHY 30 & 0.72 & 24 & $2.15^{a}$ & 46 & 0.65 & 30 \\
\hline FRU 30 & 0.86 & 30 & 1.03 & 20 & 0.30 & 14 \\
\hline Statistical analysis & $P<0.0001$ & $P<0.085$ & $P<0.0013$ & $P<0.005$ & $P<0.0001$ & $P<0.023$ \\
\hline SUC 15 & 2.34 & 68 & 2.97 & 52 & 2.24 & 56 \\
\hline
\end{tabular}

\footnotetext{
a: treatments which are statistically superior to others, using Gupta's test at a $99 \%$ probability level.
} 


\section{CONCLUSIONS}

The carbohydrates strongly influenced intensive vegetative multiplication and rooting of Malus Jork9. The results obtained during proliferation differed from those obtained previously with $\mathrm{Mal}$ us EM IX (Seingre et al, 1991): hydrolysed sucrose as well as all associations providing fructose more or less rapidly provoked the appearance of symptoms of "cancerisation" (Gaspar et al, 1991). These observed symptoms, ie extreme rejuvenation, decreased lignification, increased budding, dull blue-green aspect of the leaves) are comparable to those obtained in the presence of very high BAP levels.

In parallel with Lane (1978), we have noticed growth degradation but no reduction in rooting with media containing $<2 \%$ sucrose.

The morphological aspect of the microcuttings generated from a sorbitol-containing medium leads us to consider that this sugar was not only utilised by the plant, but that it could alter plant carbon heterotrophy to a mixotrophic state.

During rooting, the carbohydrates used also play an important role. Whatever the sugar considered $(0.088 \mathrm{M})$, the number of roots formed was superior when the proliferation sugar was replaced with either sucrose or glucose. At $0.176 \mathrm{M}$, it is particularly important to underline the effectiveness of sorbitol used during both phases of culture; these results, which are in contradiction with those of Kikuta and Okazawa (1984) and previous results obtained on Malus EM IX (Moncousin, 1992), clearly show that the ontogenic, physiological and genotypical states have a considerable importance in the study of these phenomena. The softening effect of fructose on the gelification of culture media has already been evidenced (Owen et al, 1991), but the negative influence has not been evidenced for other plant material. We cannot yet determine whether the cancer symptoms found, which were more prominent as the amount of fructose increased, were provoked by the presence of furfural and hydroxymethyl-furfural, resulting from autoclaving (Uosukainen and Vasara, 1992); we would be more inclined to think that the "cancerisation" of Malus Jork 9 was a consequence of BAP intoxication; this could have been caused by an increased penetration of the plant hormone due to a greater surface in contact with the medium.

\section{ACKNOWLEDGMENTS}

This study was completed within the EEC BRIDGECOST 87 action and partially supported by the OFES (Office Fédéral de l'Education et de la Science) in Berne. We are grateful to these institutions for their financial support.

\section{REFERENCES}

Boulay M (1979) Propagation in vitro du Douglas (Pseudotsuga menziesii (Mirb)) par micropropagation de germination aseptique et culture de bourgeons dormants. In: Micropropagation d'Arbres Forestiers. Ann AFOCEL 12(6), 67-75

Chalupa V (1977) Organogenesis in Norway spruce and Douglas fir tissue cultures. Commun Inst For Technol 10, 79-87

Cheng TY, Voqui T (1977) Regeneration of Douglas fir plantlets through tissue culture. Science 198, 306307

Chong C, Tapper CD (1974) Malus tissue culture. II. Sorbitol metabolism and carbon nutrition. Can J Bot $52,2361-2364$

Coffin R, Tapper CD, Chong C (1976) Sorbitol and sucrose as carbon source for callus culture of some species of the Rosaceae. Can J Bot 54, 547-551

Driver JA, Suttle GRL (1987) Nursery handling of propagules. In: Cell and Tissue Culture in Forestry (Bonga JM, Durzan DJ, eds) Martinus Nijhoff, Dordrecht, 320-335

Druart $P$, De Wulf $Q$ (1990) Activated charcoal catalyses sucrose hydrolysis during autoclaving. In: Abstr VIIth Int Congr Plant Tissue Cell Culture. Amsterdam, June 24-29, 1990, 97

Eliasson L, Brunes L (1980) Light effects on root formation in aspen and willow cuttings. Physiol Plant $48,261-265$

Eng-Chong $P$ (1983) Morphogenesis and physiology of Malus tissues and cells in vitro. Ph D Thesis, Dept Plant Sci, Mc Gill Univ, QE, Canada

Gaspar T, Hagège D, Kevers C, Penel C, Crèvecœur $M$, Engelmann I, Greppin H, Foidart JM (1991) When plants teratomas turn into cancers in the $a b$ sence of pathogens. Physiol Plant 83, 696-701

George EF, Sherington PD (1984) Plant Propagation by Tissue Culture. Exegetics Ltd, Hants, UK, 224225

Grant CR, Rees TA (1981) Sorbitol metabolism by apple seedlings. Phytochemistry 20, 1505-1511

Haissig BE (1984) Carbohydrate accumulation. Physiol Plant 61, 13-19

Hyndman SE, Hasegawa PM, Bressan RA (1982) Stimulation of root initiation from cultured rose shoots through the use of reduced concentrations of mineral salts. HortSci $17,82-83$ 
James DJ, Thurbon IJ (1981) Shoot and root initiation in vitro in the apple rootstock M9 and the promotive effects of phloroglucinol. J Hortic Sci 56, 15-20

Kikuta Y, Okazawa $Y$ (1984) Control of root and shoot bud formation from potato tuber tissue cultured in vitro. Physiol Plant 61, 8-12

Kozai T (1991) Micropropagation under photoautotrophic conditions. In: Micropropagation Technology and Application (Debergh PC, Zimmerman $\mathrm{RH}$, eds) Kluwer Academic Publ, Dordrecht, 447.469

Lane WD (1978) Regeneration of apple plants from shoot meristem tips. Plant Sci Lett 13, 281-285

Moncousin C (1992) Rooting of in vitro cuttings. In: Biotechnology in Agriculture and Forestry (Bajaj YPS, eds) Springer Verlag, Hèidelberg, vol 17, 231-261

Owen HR, Wengerd D, Miller AR (1991) Culture medium $\mathrm{pH}$ is influenced by basal medium, carbohydrate source, gelling agent, activated charcoal, and medium storage method. Plant Cell Rep 10, 583-586
Seingre D, O'Rourke J, Gavillet S, Moncousin C (1991) Influence of gelling agent and carbon source on the in vitro proliferation rate of apple rootstock EM IX. Acta Hortic 289, 151-155

Snir I, Erez A (1980) In vitro propagation of Malling Merton apple rootstocks. HortSci 15, 597-598

Thorpe TA (1974) Carbohydrate availability in shoot formation in tobacco callus cultures. Physiol Plant $30,77-81$

Timmis R, Ritchie GA (1984) Progress in Douglas fir tissue culture. Proc Int Symp Recent Adv For Biotechnol. Traverse City, 37-46

Uosukainen M, Vasara T (1992) Effects of autoclaving on micropropagation medium. In: COST 87 Session. Dijon, 1992

Welander $T$ (1976) Effect of nitrogen, sucrose, IAA and kinetin on explants of Beta vulgaris grown in vitro. Physiol Plant 36, 7-10 